\title{
OKSIGEN TERLARUT DI SELAT LOMBOK
}

\author{
DISSOLVED OXYGEN IN LOMBOK STRAIT
}

\author{
Faisal Hamzah dan Mukti Trenggono \\ Balai Penelitian dan Observasi Laut, Balitbang KP, KKP \\ Jl. Baru Perancak, Negara, Jembrana, Bali 82251 \\ E-mail: faisalhamzah@kkp.go.id
}

Diterima tanggal:17 Desember 2013, diterima setelah perbaikan: 1 Maret 2014, disetujui tanggal: 7 Maret 2014

\begin{abstract}
ABSTRAK
Oksigen merupakan gas penting dalam perairan laut dan berperan dalam proses biogeokimia laut. Sumber oksigen berasal dari difusi dari udara melalui proses turbelensi dan hasil fotosintesis. Penelitian ini bertujuan untuk mengkaji distribusi dan pengaruh Indonesian Throughflow (ITF) terhadap konsentrasi oksigen terlarut di Selat Lombok. Sebanyak 11 stasiun (3 di utara; 6 di tengah; 2 di selatan) dianalisis kandungan oksigen terlarutnya dengan menggunakan metode modifikasi winkler. Hasil analisis menunjukan bahwa kandungan oksigen di bagian utara berkisar 2,48-7,15 mg/l, tengah 2,32-6,58 mg/l dan selatan 2,35-6,71 mg/l. Berdasarkan nilai apparent oxygen utilization (-2,70-5,64 mg/l) dan normal atmospheric equilibrium concentration (3,84-7,96 mg/l), mencerminkan kandungan oksigen yang semakin berkurang pada lapisan permukaan. AOU dan NAEC secara implisit berubah terhadap kedalaman dimana konsentrasinya akan semakin tinggi dengan bertambahnya kedalaman. Hasil pengukuran suhu dan salinitas menunjukan bahwa Selat Lombok mempunyai suhu dan salinitas masing-masing berkisar antara 4,74-30,08 ${ }^{\circ} \mathrm{C}$ dan 33,48-34,78 psu. Analisis TS-diagram menunjukan terdapat dua massa air yang membawa kandungan oksigen di Selat Lombok yaitu Northern Subtropical Lower Water (NSLW) (salinitas=34,53-34,58 psu, suhu=13,5715,06 ${ }^{\circ} \mathrm{C}$; sigma-t (s t)=25,40-25,80)) dan Northern Pacific Intermediate Water (NPIW) (salinitas=34,48-34,54 psu; suhu=6,30-7,90 ${ }^{\circ} \mathrm{C}$; sigma-t (s t)=26,70-27,20). NSLW ditemukan pada kedalaman 100-180 (utara), 100-550 m (tengah) dan 190-220 m (selatan), sedangkan NPIW tidak terlihat dengan menggunakan pendekatan oksigen terlarut dan hanya bisa dilihat dengan pendekatan suhu dan salinitas.
\end{abstract}

Kata kunci: oksigen terlarut, AOU, NAEC, massa air, Selat Lombok

\begin{abstract}
Oxygen is important gases in ocean and have a role for marine biogeochemical processes. Oxygen produced by diffusion from atmosphere through turbulence processes and product of photosynthesis. This study was aimed to determine profiles and impact of Indonesian Throughflow (ITF) to dissolved oxygen concentrations in Lombok Strait. A total of eleven stations ( 3 in north; 6 in middle; 2 in south) were analyzed of dissolved oxygen concentrations using Winkler modification methods. Result showed that the concentration of dissolved oxygen in north of Lombok Strait were 2.48-7.15 $\mathrm{mg} / \mathrm{l}$, in middle 2.32-6.58 $\mathrm{mg} / \mathrm{l}$, and in south 2.35-6.71 $\mathrm{mg} / \mathrm{l}$. Apparent oxygen utilization (-2.70-5.64 $\mathrm{mg} / \mathrm{l})$ and normal atmospheric equilibrium concentration $(3.84-7.96 \mathrm{mg} / \mathrm{l})$ indicated that dissolved oxygen was decreased in mixed layer and changing implicitly with the depth where concentration higher when depth increased. Temperature and salinity measurement showed that value of both were range 4.74-30.08 $\mathrm{C}$ and 33.48-34.78 psu, respectively. Meanwhile TS-diagram showed there were two of water masses consist of dissolved oxygen in Lombok Strait are Northern Subtropical Lower Water $(N S L W)$ (salinity $=34.53-34.58 \mathrm{psu}$, temperature $=13.57-15.06{ }^{0} \mathrm{C}$; potential temperature $(\mathrm{s}$ $t)=25,4-25,8)$ and Northern Pacific Intermediate Water $(N P I W)$ (salinity $=34.48-34.54 p s u ;$ temperature $=6.30-7.90{ }^{\circ} \mathrm{C}$; potential temperature $(s t)=26.70-27.20)$. NSLW was found at a depth of 100-180 $\mathrm{m}$ (north), 100-550 m (middle) and 190-220 m (south), while NPIW not seen clearly by using dissolved oxygen approach and can only be seen by using temperature and salinity approach.
\end{abstract}

Keywords: dissolved oxygen, AOU, NAEC, water masses, Lombok Strait 


\section{PENDAHULUAN}

Selat Lombok merupakan salah satu lintasan dari Arus Lintas Indonesia (Indonesian Througflow) yang membawa massa air dari Samudera Pasifik menuju Samudera Hindia selain melalui Selat Ombai dan Laut Timor. Sekitar 1,7 Sv massa air yang melintasi selat ini (Murray dan Arief, 1988; Gordon, 2005). Batimetri dibagian utara dan tengah Selat Lombok mempunyai kedalaman hingga $1400 \mathrm{~m}$ sedangkan di bagian selatan, terdapat pulau Nusa Penida yang memisahkan selat ini menjadi dua bagian dimana di bagian barat (Selat Badung) memiliki kedalaman yang lebih dangkal $(100 \mathrm{~m})$ dibandingkan dengan perairan di bagian timur $(250 \mathrm{~m})$ serta terdapat sill (Susanto et al., 2005).

Selain mempengaruhi proses fisik, massa air yang melintasi di Selat Lombok juga akan mempengaruhi parameter kimia dan biologi salah satunya adalah oksigen terlarut. Oksigen merupakan unsur kimia penting yang digunakan sebagai penunjang dalam kehidupan organisme dan banyak berperan dalam siklus biogeokimia laut. Oksigen diproduksi melalui proses fotosintesis dan difusi antara air dengan udara (Nybakken 1988; Libes, 1992). Rendahnya nilai oksigen dimanfaatkan untuk proses respirasi.Oksigen akan berkurang dan digunakan untuk mengoksidasi bahan organik $\left(\left(\mathrm{CH}_{2} \mathrm{O}\right)_{106}\left(\mathrm{NH}_{3}\right)_{16}\left(\mathrm{H}_{3} \mathrm{PO}_{4}\right)\right)$, sedangkan $\mathrm{CO}_{2}$, $\mathrm{HNO}_{3}, \mathrm{H}_{3} \mathrm{PO}_{4}, \mathrm{danH}_{2} \mathrm{O}$ akan bertambah (Libes, 1992).

Pada lapisan permukan, selain melalui proses fotosintesis, tingginya konsentrasi oksigen pada lapisan ini juga disuplai oleh kelarutan oksigen dari atmosfer melalui proses difusi. Saat oksigen berada dalam kondisi setimbang (laju perubahan antara atmosfer dan air sama) dan proses yang terjadi bersifat bolak balik (reversible), maka kelarutan oksigen dari atmosfer akan bergerak menuju lapisan permukaandan dikenal dengan istilah normal atmospheric equilibrium concentration (NAEC). Proses tersebut hanya berlaku pada lapisan eufotik saja. Pada lapisan yang lebih dalam, kandungan oksigen disuplai melalui penenggelaman massa air dimana membawa kandungan oksigen yang tinggi dari permukaan (Libes, 1992). Oksigen pada lapisan ini akan tetap rendah dikarenakan digunakan untuk menguraikan bahan-bahan organik dan detritus yang terdekomposisi dari lapisan permukaan dan termoklin (Riley dan Chester, 1971; Libes, 1992).

Penelitian mengenai oksigen terlarut di lintasan Indonesian Throughflow terutama di Selat Lombok belum banyak dilakukan. Umumnya kajian lebih ditekankan pada proses fisika oseanografi (Murray dan Arief, 1988; Gordon, 2005; Susanto et al., 2005; Utami; 2005; Karang et al., 2012), nutrient dan konsentrasi khlorofil-a (Hani, 2006). Untuk itu dilakukan penelitian mengenai distribusi oksigen terlarut dan dikaitkan dengan massa air yang melintas di Selat Lombok. Penelitian ini bertujuan untuk mengkaji distribusi oksigen terlarut dan pengaruh Indonesian Throughflow yang melintas terhadap konsentrasi oksigen terlarut di Selat Lombok.

\section{BAHAN DAN METODE}

\subsection{Waktu dan Lokasi Penelitian}

Kegiatan penelitian dilaksanakan pada bulan November 2013 di Selat Lombok. Sebanyak 11 stasiun diambil dalam penelitian ini. Stasiun 1, 2 dan 3 merupakan stasiun yang berada di utara, stasiun 4, 5, 6, 7, 8, dan 9 merupakan stasiun yang berada di bagian tengah, sedangkan stasiun 11 dan 12 merupakan stasiun yang berada di selatan Selat Lombok (Gambar 1). Pelaksanaan kegiatan merupakan kegiatan kerjasama "Effect of South China Sea on Lombok Strait Throughflow" antara Balai Penelitian dan Observasi Laut, Balitbang KP-KKP dengan First Institute of Oceanography (FIO), State Oceanic Administration (SOA), China. Kegiatan penelitian dilaksanakan dengan menggunakan Kapal Riset Baruna Jaya IV.

\subsection{Pengambilan dan Analisis Sampel}

Sampel air diambil dengan menggunakan Rossette Bottle yang terangkai pada alat pengukur dan perekam konduktivitas, suhu dan kedalaman (Conductivity, Temperature, Depth=CTD) dengan volume 8 liter. Sampel air diambil tiap kedalaman tertentu yang mewakili lapisan tercampur (mixed layer), lapisan termoklin dan lapisan dalam. Tiap stasiun memiliki kedalaman yang berbeda. Untuk stasiun yang berada di utara Selat Lombok memiliki kedalaman lebih dari $1000 \mathrm{~m}$, sedangkan di tengah berkisar antara 300-1100 $\mathrm{m}$ dan dibagian selatan memiliki kedalaman berkisar antara 500-750 m (Tabel 1). 


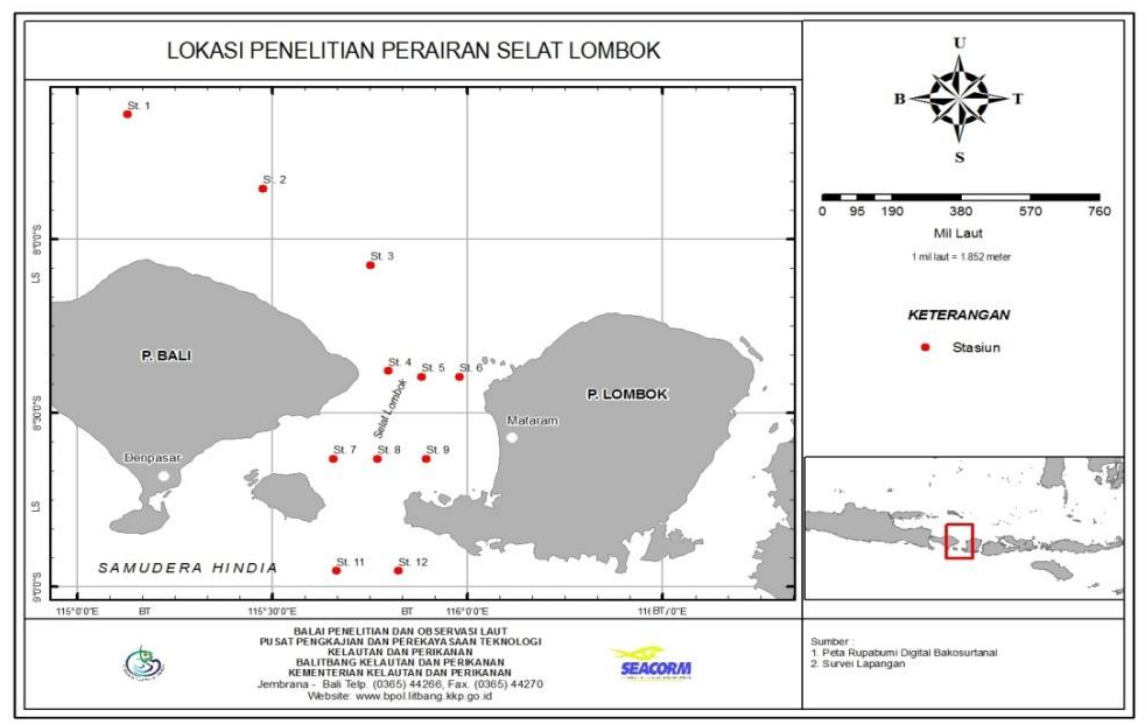

Gambar 1. Lokasi penelitian.

Figure 1. Research location

Sumber: Peta Rupabumi Digital Bakosurtanal dan hasil survei lapangan

Tabel 1. Kedalaman pengambilan sampel tiap stasiun

Table 1. Water depth for measurement dissolved oxygen

\begin{tabular}{cl}
\hline Stasiun & \multicolumn{1}{c}{ Kedalaman pengambilan sampel $(\mathrm{m})$} \\
\hline St. 01 & $5,25,50,75,100,150,200,250,300,400,500$ dan 650 \\
\hline St. 02 & $5,25,50,75,100,150,200,300,400,500,750$ dan 1000 \\
\hline St. 03 & $5,25,50,75,100,150,200,300,400,500,750$ dan 1000 \\
\hline St. 04 & $25,75,150,250,500$ dan 750 \\
\hline St. 05 & $5,25,75,150,200,500$ dan 750 \\
\hline St. 06 & $25,75,150,250,500,750$ dan 1000 \\
\hline St. 07 & $25,75,100,150,200$ dan 250 \\
\hline St. 08 & $25,150,200,300,350$ dan 450 \\
\hline St. 09 & $25,100,200,300,350$ dan 450 \\
\hline St. 11 & $5,25,50,75,100,125,150,175,200,250,300$ dan 400 \\
\hline St. 12 & $25,75,150,250,300$ dan 350 \\
\hline
\end{tabular}

Sumber: Hasil survei lapangan

Saat CTD turun, dilakukan perekaman suhu dan salinitas. Perubahan ketiga lapisan (lapisan tercampur, lapisan termoklin dan lapisan dalam) bisa diketahui berdasarkan rekam plot saat diturunkan CTD. Saat CTD naik, dilakukan pengambilan sampel air sesuai dengan kedalaman yang telah ditentukan. Setelah sampel air naik di permukaan, maka dengan segera sampel dimasukan kedalam botol BOD (ukuran $300 \mathrm{ml}$ ). Sampel air dimasukan dengan menggunakan selang karet sampai ke permukaan dengan tujuan untuk menghindari gelembung gas dalam botol BOD. Setelah tidak gelembung gas dan air dibiarkan tumpah kira-kira 1/3 volume botol BOD, kemudian selang karet diangkat/ dikeluarkan dengan pelan-pelan dan botol ditutup hingga siap dianalisis kandungan oksigennya (Hutagalung et al., 1997).

Pengukuran oksigen dilakukan dengan menggunakan metode modifikasi winkler, dimana larutan yang bersifat basa kuat $\left(\mathrm{MnSO}_{4}\right)$ bereaksi dengan dengan $\mathrm{OH}$ dan membentuk endapan $\mathrm{Mn}(\mathrm{OH})_{2}$ yang berwarna putih. Endapan $\mathrm{Mn}(\mathrm{OH})_{2}$ bersifat tidak stabil, sehingga segera dioksidasi oleh oksigen yang berada di dalam contoh dan menjadi $\mathrm{Mn}(\mathrm{OH})_{3}$. Kemudian $\mathrm{Mn}(\mathrm{OH})_{3}$ akan larut kembali setelah diberi dengan asam kuat $\left(\mathrm{H}_{2} \mathrm{SO}_{4}\right)$ dan melepaskan $\mathrm{Mn}^{3+}$ yang bersifat oksidator. Ion $\mathrm{Mn}^{3+}$ akan mengoksidasi 
ion Iodida menjadi $\mathrm{I}_{2}$ bebas. Banyaknya $\mathrm{I}_{3}{ }^{-}$yang terbentuk akan ekuivalen dengan endapan $\mathrm{Mn}(\mathrm{OH})_{3}$. Kemudian larutan tersebut dititrasi dengan menggunakan natrium tiosulfat memakai indikator amilum. Titrasi dihentikan saat larutan berubah warna dari biru keungu-unguan menjadi tidak berwarna. Banyaknya $\mathrm{I}_{3}^{-}$adalah ekuivalen dengan banyaknya $\mathrm{S}_{2} \mathrm{O}_{3}{ }^{2-}$. Banyaknya $\mathrm{S}_{2} \mathrm{O}_{3}{ }^{2-}$ akan ekuivalen dengan banyaknya oksigen terlarut dalam contoh (Grasshoff, 1976; Parson et al., 1984; Hutagalung et al., 1997).

\subsection{Analisis Data}

Kandungan oksigen yang telah dihitung konsentrasinya kemudian diplotkan berdasarkan lokasi stasiun (utara, tengah, dan selatan Selat Lombok). Hasil perekaman suhu dan salinitas nantinya dibuat juga profil distribusi vertikal suhu dan salinitas. Untuk mengetahui asal massa air yang melintas di Selat Lombok maka dibuatlah T-S diagram. T-S diagram dibuat dengan cara memasukan parameter suhu, salinitas dan kedalaman untuk diketahui suhu potensialnya. Nantinya massa air yang melintas ini, akan mempengaruhi kandungan oksigen terlarut. Untuk menggambarkan konsentrasi oksigen, suhu, salinitas dan massa air, dilakukan dengan menggunakan program Ocean Data View 4.5.7 (Schlitzer, 2013).

Kelarutan oksigen $\left(\mathrm{O}_{2}{ }^{\prime}\right)$ pada saat setimbang (NAEC) (ml/l))dapat diketahui pada suhu (T (K)) dan salinitas (S (psu)) insitu, maka dilakukan perhitungannya dengan menggunakan rumus (Garcia dan Gordon, 1992):

$$
\begin{aligned}
& 02^{\prime}=\exp \left(-173,4292+249,6339\left(\frac{100}{T}\right)+\right. \\
& \left.143,3438 \ln \left(\frac{T}{100}\right)-21,8492\left(\frac{T}{100}\right)\right)+ \\
& S\left(-0,033096+0,014259\left(\frac{T}{100}\right)-\right. \\
& \left.\left.0,00170\left(\frac{T}{100}\right)^{\wedge} 2\right)\right)
\end{aligned}
$$

\section{Catatan $1 \mathrm{ml} / \mathrm{L}=1,4286 \mathrm{mg} / \mathrm{l}$}

Selain kandungan oksigen yang diukur secara insitu, banyaknya oksigen yang dibutuhkan untuk proses respirasi dan penguraian zat-zat organik oleh mikroorganisme yang dikenal dengan istilah Apparent Oxygen Utilization (AOU). AOU didapatkan berdasarkan nilai daya larut oksigen pada saat NAEC dikurangi dengan hasil pengukuran oksigen secara in situ $\left(\mathrm{O}_{2}\right)$ (Redfield, 1942; Libes, 1992):

$\mathrm{AOU}(\mathrm{mg} / \mathrm{l})=\mathrm{O}_{2}{ }^{\prime}-\mathrm{O}_{2}$

\section{HASIL DAN PEMBAHASAN}

\subsection{Oksigen Terlarut}

Untuk mempermudah dalam menganalisis, daerah penelitian dibagi menjadi 3 bagian yaitu utara Selat Lombok (stasiun 1, 2 dan 3), tengah Selat Lombok (stasiun 4, 5, 6, 7, 8, dan 9) dan selatan Selat Lombok (11 dan 12). Secara umum hasil kandungan oksigen terlarut di utara berkisar antara antara 2,48-7,14 mg/l. Nilai oksigen terlarut pada daerah ini tertinggi terdapat pada stasiun 1 kedalaman $75 \mathrm{~m}$ dan terendah terdapat pada stasiun 2 kedalaman $1000 \mathrm{~m}$. Pada bagian tengah, nilai kandungan oksigen terlarut berkisar antara 2,31-6,57 mg/l dengan kandungan tertinggi terdapat pada stasiun 8 kedalaman $25 \mathrm{~m}$ dan terendah terdapat pada stasiun 6 kedalaman 1000 m. Pada bagian selatan Selat Lombok, nilai oksigen terlarut berkisar antara 2,34-6,71 mg/l. Kandungan oksigen tertinggi terdapat pada stasiun 11 kedalamn $5 \mathrm{~m}$ dan terendah terdapat pada stasiun 11 kedalaman $300 \mathrm{~m}$ dan $350 \mathrm{~m}$. Nilai oksigen di Selat Lombok umumnya lebih tinggi dibandingkan perairan Belitung Timur (2,67-3,10 $\mathrm{mg} / \mathrm{l})$ perairan Banggai, Sulawesi Tengah $(1,50$ $2,90 \mathrm{mg} / \mathrm{l})$, perairan Banten $(1,51-3,00 \mathrm{mg} / \mathrm{l})$ dan perairan Membramo, Papua (2,17-2,66 mg/l) (Simanjuntak, 2012).

\section{a. Stasiun 1, 2 dan 3}

Pada bagian utara Selat Lombok, nilai kandungan oksigen terlarut bervariasi terhadap kedalaman. Umumnya nilai oksigen tinggi di permukaan dan semakin berkurang kandungannya dengan bertambahnya kedalaman. Berdasarkan Gambar 2, dapat dilihat bahwa pada daerah permukaan stasiun $1(0-100 \mathrm{~m})$, kandungan oksigen terlihat lebih tinggi dibandingkan dengan daerah permukaan stasiun lainnya. Kandungan oksigen pada kedalaman tersebut berkisar antara 5,74-7,15 $\mathrm{mg} / \mathrm{l}$. Hal tersebut disebabkan aktivitas fotosintesis oleh fitoplankton yang menghasilkan oksigen dan proses difusi dari atmosfer ke air. Tinggi rendahnya oksigen dalam perairan juga dipengaruhi oleh kelarutan (solubity), suhu, dan salinitas (Riley dan Chester, 1971). Pada stasiun 2 , khususnya daerah permukaan $(0-25 \mathrm{~m})$, nilai 
DO cenderung tinggi, namun pada kedalaman 25$100 \mathrm{~m}$, nilai oksigen berkurang. Berkurangnya oksigen pada kedalaman tersebut lebih disebabkan oleh aktivitas respirasi dan menguraikan zat organik menjadi anorganik oleh mikroorganisme (Nybakken, 1988). Kandungan oksigen terlarut pada kedalaman 0-25 m dan 25-100 m masingmasing berkisar antara 4,19-4,40 mg/l dan 3,19$3,76 \mathrm{mg} / \mathrm{l}$.

Pada kedalaman $200 \mathrm{~m}$, nilai DO kembali meningkat dengan konsentrasi sebesar 5,23 mg/l. Di stasiun 3, nilai DO cenderung memiliki pola yang sama dengan stasiun 2, namun hanya berbeda kedalamannya saja. Pada kedalaman permukaan 0-50 $\mathrm{m}$, nilai DO konsentrasinya lebih tinggi dandibandingkan dengan lainnya (4,63-5,50 $\mathrm{mg} / \mathrm{l})$. Pada kedalaman $200 \mathrm{~m}$, konsentrasi DO menurun namun nilainya lebih tinggi dibandingkan dengan stasiun 2, yaitu 3,66 mg/l. Nilai oksigen terlarut pada daerah utara Selat Lombok mulai stasiun 1 hingga stasiun 3, terlihat bahwa semakin menuju stasiun 3,kedalaman yang memiliki konsentrasi DOsemakin dalam. Sebagai contoh, pada konsentrasi DO $=3,5 \mathrm{mg} / \mathrm{l}$, pada stasiun 1 ditemukan pada kedalaman sekitar $180 \mathrm{~m}$. Kemudian pada stasiun 2, kedalaman yang memiliki DO sebesar 3,5 mg/l adalah $380 \mathrm{~m}$, sedangkan pada stasiun 3 ditemukan pada kedalaman sekitar $600 \mathrm{~m}$. Selain faktor batimetri dimana pada stasiun 1 lebih dangkal dibandingkan stasiun 2 dan 3, pengaruh Indonesian Throughflow yang melintas dari utara Selat Lombok menuju Selat Lombok diduga mempengaruhi nilai DO. Proses pengadukandan sirkulasi massa air (thermohaline circulation) yang terjadi di ketiga stasiun khususnya pada kedalaman 150-200 sampai $1000 \mathrm{~m}$ diduga mampu meningkatkan nilai DO dan terjadi penenggelaman fluks dari bahan organik (detritus) menjadi lebih kecil (Libes, 1992). Selain itu juga proses yang terjadi juga mengontrol ketersedian nutrien, salinitas dan karbon (Ramesh et al., 2013).

\section{b. Stasiun 4, 5, 6, 7, 8 dan 9}

Pada bagian tengah Selat Lombok terdapat 6 stasiun dan dibagi menjadi dua bahasan berdasarkan cross section yaitu stasiun 4, 5, dan 6 serta stasiun 7, 8, dan 9. Pada bahasan pertama (Gambar 3), terlihat bahwa pada lapisan permukaan di stasiun 4, oksigen terlarut cenderung tinggi yaitu 4,90-6,44 mg/l.
Konsentrasi oksigen tinggi pada stasiun ini hingga kedalaman $200 \mathrm{~m}$. Kondisi tesebut juga ditemukan pada stasiun 5-6, nilai oksigen juga tinggi di daerah permukaan khususnya pada kedalaman 5-25 m (5,30-6,28 mg/l dan 3,89$4,77 \mathrm{mg} / \mathrm{l})$.

Semakin bertambahnya kedalaman, konsentrasi oksigen terlarut semakin berkurang. Hal ini disebabkan oleh proses fotosintesis tidak efektif pada kedalam tersebut sehingga terjadi penurunan oksigen terlarut sampai ke suatu kedalaman tertentu dan nilainya sama (Compensation Depth) (Riley dan Chester, 1971). Berdasarkan Gambar 3, dapat dilihat bahwa daerah timur Pulau Bali/barat Selat Lombok lebih tinggi konsentrasi oksigennya dibandingkan dengan timur Selat Lombok. Terjadi perbedaan konsentrasi oksigen antarkedalaman sepanjang cross section ini.Konsentrasi oksigen sebesar $5 \mathrm{mg} / \mathrm{l}$ pada timur Selat Lombok hanya berada kedalaman sekitar 25 $\mathrm{m}$, namun semakin kearah barat konsentrasi tersebut mencapai kedalaman $50 \mathrm{~m}$ di stasiun 5 dan $230 \mathrm{~m}$ pada stasiun 4. Hal ini diduga oleh adanya peningkatan bahan organik di bagian timur Selat Lombok. Di bagian timur, sering dijumpai banyak aktivitas pertanian, aktivitas rumah tangga dan pariwisata (Gili Matra) yang mampu meningkatkan bahan organik.

Pengaruh Indonesian Throughflow (ITF) yang melintas di daerah barat Selat Lombok diduga menjadi penyebab tingginya nilai DO di wilayah barat Selat Lombok.Massa air dari Pasifik melintasi bagian barat Selat Lombok yang memiliki kedalaman lebih dari $1.000 \mathrm{~m}$. Hal ini bisa dilihat dari hasil pengukuran dimana bagian barat pada kedalaman $>800 \mathrm{~m}$ lebih tinggi dibandingkan di bagian timur. Pengaruh tingkat kelarutan oksigen akan meningkat pada suhu yang lebih rendah, sehingga akan menenggelamkan massa air yang kaya akan oksigen (Libes, 1992). Daerah hipoksia (dimana konsentrasi oksigen dibawah $2 \mathrm{mg} / \mathrm{l}$ ) belum terjadi pada stasiun 4, 5, dan 6. Namun pada stasiun 6, terdapat konsentrasi oksigen yang mendekati hipoksia namun konsentrasinya lebih tinggi yaitu berkisar $2,5 \mathrm{mg} / \mathrm{l}$ pada kedalaman $600 \mathrm{~m}$.

Kandungan oksigen terlarut pada stasiun 7,8 dan 9 menunjukan tinggi dipermukaan dan rendah pada kiri dan kanan selat terutama kedalaman 200-350 m disisi kiri selat dan kedalaman lebih 
dari $400 \mathrm{~m}$ di sisi kanan selat. Pada lapisan permukaan, nilai oksigen pada stasiun 7 lebih rendah dari pada stasiun 8 , namun lebih tinggi dibandingkan dengan stasiun 9. Nilai oksigen terlarut pada stasiun ini berkisar antara 4,53-5,67 $\mathrm{mg} / \mathrm{l}$. Pada kedalaman yang lebih dalam, nilai oksigen cenderung terstratifikasi. Pada stasiun ini, kedalaman dasar yang dianalisis oksigennya adalah $250 \mathrm{~m}$. Semakin menuju ke stasiun 8, kedalaman semakin bertambah. Pada kedalaman lebih dari $25 \mathrm{~m}$, nilai oksigen adalah $4,5 \mathrm{mg} / \mathrm{l}$. Nilai tersebut masih stabil hingga kedalaman $125 \mathrm{~m}$ menuju tengah selat (Gambar 4). Hal yang sama juga terjadi pada kandungan oksigen 3,5 mg/l, dimana konsentrasinya stabil hingga kedalaman $350 \mathrm{~m}$ menuju tengah selat.

Pola distribusi oksigen pada stasiun 8 juga sama dengan stasiun lainnya. Pada stasiun ini, nilai oksigen tinggi dipermukaan dan semakin rendah dengan bertambahnya kedalaman. Nilai oksigen pada permukaan $(25 \mathrm{~m})$ lebih tinggi dibandingkan dengan kedalaman lainnya yaitu $6,58 \mathrm{mg} / \mathrm{l}$. Pada kedalaman 25-200 m, konsentrasi oksigen juga terlihat masih tinggi, namun konsentrasinya tidak setinggi dipermukaan. Pada kedalaman lebih dari $400 \mathrm{~m}$ stasiun 8 , nilai oksigen cenderung tinggi dibandingkan dengan stasiun 1, 2, 3, 4, 5 dan 6 . Kandungan oksigen pada kedalaman tersebut mencapai 3,49-3,59 mg/l. Pola distribusi oksigen pada stasiun 9 lebih mirip dengan stasiun 7 . Pada daerah permukaan $(25-100 \mathrm{~m})$, nilai oksigen terlarut berkisar antara 4,90-5,03 mg/l. Nilai oksigen semakin menurun konsentrasinya terutama pada kedalaman lebih dari $100 \mathrm{~m}$ hingga $450 \mathrm{~m}$ yaitu 3,83-2,75 mg/l. Stasiun 9 lebih dekat dengan Pulau Lombok dimana banyak aktivitas yang menghasilkan bahan organik. Dampak ini akan berakibat pada rendahnya nilai oksigen terlarut. Berkurangnya oksigen terlarut diduga disebabkan oleh remineralisasi dari bahan organik yang dihasilkan di zona eufotik. Kemudian terdisposisi ke lapisan yang lebih dalam oleh gravitasi dan proses downwelling.

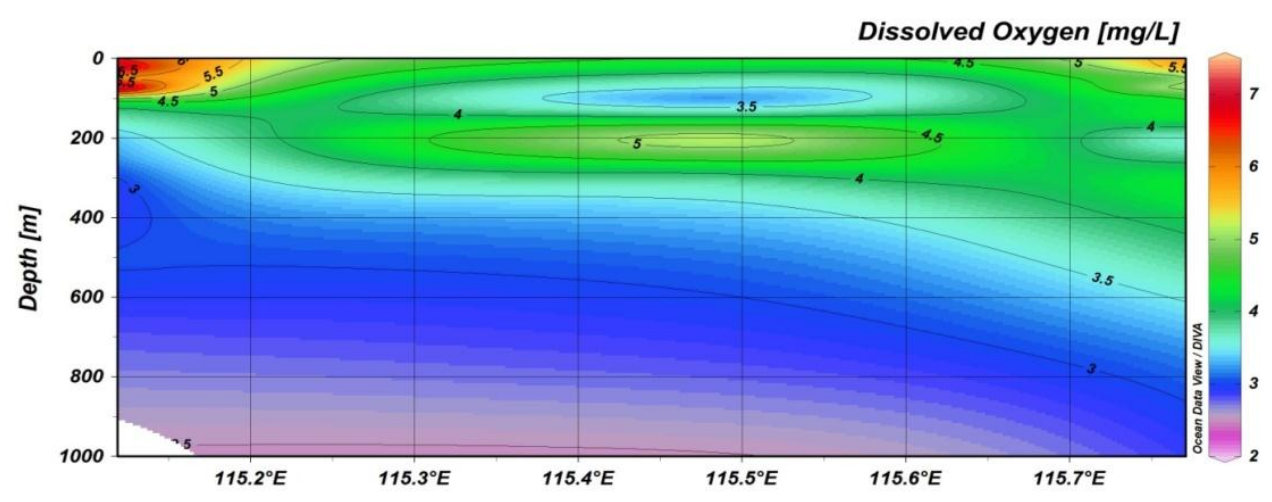

Gambar 2. Distribusi vertikal oksigen terlarut di Utara Selat Lombok.

Figure 2. Vertical distribution of dissolved oxygen in Northern of Lombok Strait Sumber: Hasil pengolahan data

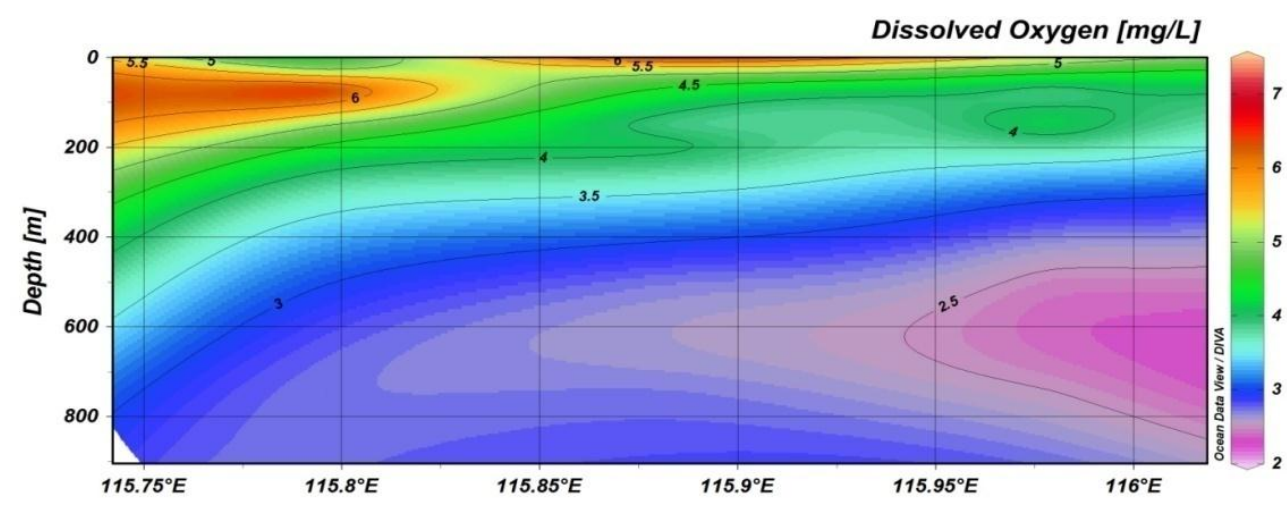

Gambar 3. Distribusi vertikal oksigen terlarut di tengah (St. 4-6) Selat Lombok.

Figure 3. Vertical distribution of dissolved oxygen in middle (St. 4-6) of Lombok Strait Sumber: Hasil pengolahan data 


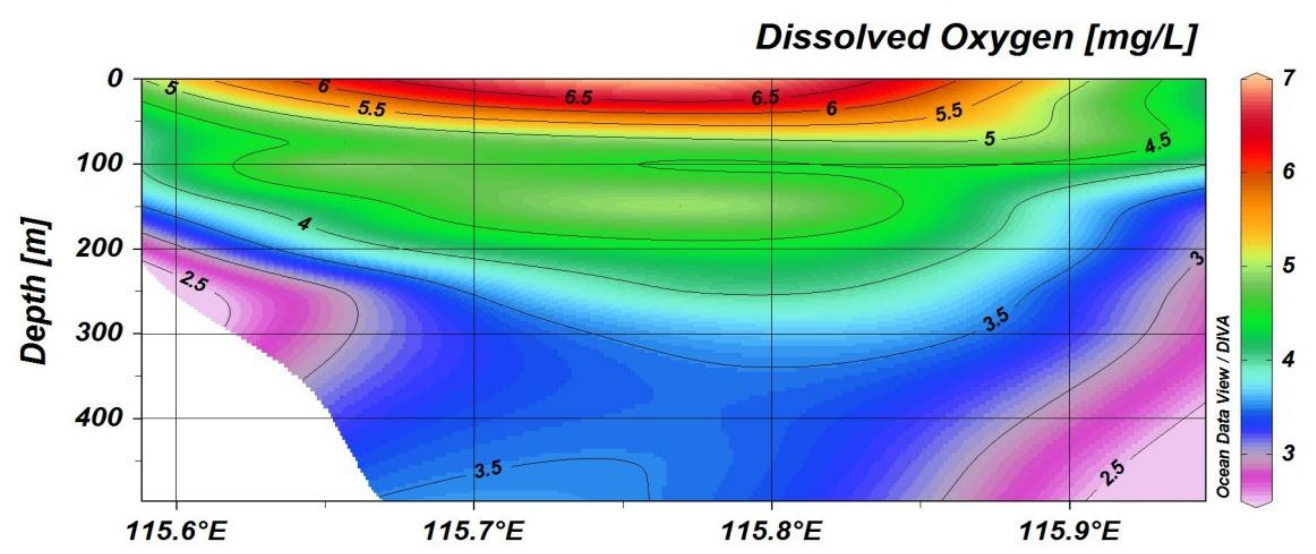

Gambar 4.Distribusi vertikal oksigen terlarut di tengah (St. 7-9) Selat Lombok.

Figure 4. Vertical distribution of dissolved oxygen in middle (St. 7-9) of Lombok Strait Sumber: Hasil pengolahan data

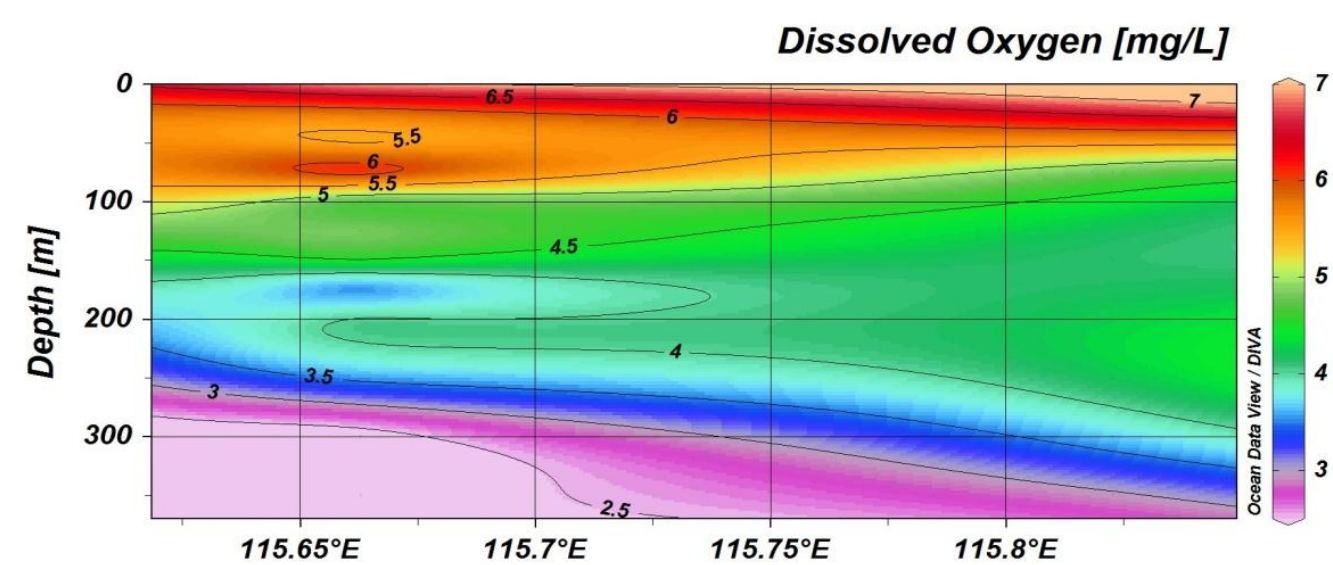

Gambar 5. Distribusi vertikal oksigen terlarut di Selatan Selat Lombok.

Figure 5. Vertical distribution of dissolved oxygen in Southern of Lombok Strait Sumber: Hasil pengolahan data

\section{c. Stasiun 11 dan 12}

Hasil analisis oksigen terlarut pada stasiun yang berada di selatan Selat Lombok menunjukan variasi oksigen tiap kedalaman. Variasi tersebut disebabkan oleh posisi dari kedua stasiun merupakan jalur akhir dari lintasan ITF dimana massa air dari Pasifik bertemu dengan massa air dari Hindia. Berdasarkan Gambar 5 dapat dilihat bahwa, pada lapisan permukaan di bagian barat (St. 11), nilai DO cenderung tinggi dibandingkan dengan timur Selat Lombok (St. 12). Proses pengadukan yang terjadi dibagian barat diduga lebih kuat dibandingkan dengan bagian timur, sehingga mampu meningkatkan nilai oksigen. Pada bagian barat, di kedalaman 0-100 m konsentrasi oksigen berkisar antara 4,66-6,71 $\mathrm{mg} / \mathrm{l}$. Namun, pada bagian timur di kedalaman tersebut, nilai oksigen bervariasi tiap kedalaman.
Pada lapisan permukaan hingga kedalaman $30 \mathrm{~m}$ nilai oksigen sekitar7 mg/l. Kemudian di kedalaman 30-60 m, nilai oksigen adalah 5-6 $\mathrm{mg} / \mathrm{l}$. Nilai oksigen pada kedua stasiun memperlihatkan pola tidak seragam pada kisaran oksigen 5-6 mg/l.Terlihat pada bagian barat selatan Selat Lombok, kedalaman yang memiliki nilai oksigen $5-6 \mathrm{mg} / \mathrm{l}$ berada pada kedalaman20$110 \mathrm{~m}$, sedangkan pada bagian timur pada kedalaman 40-60 m. Perbedaan tersebut lebih didasarkan pada pengaruh massa air yang melintas pada bagian barat lebih dominan dibandingkan dengan daerah timur. Pada bagian barat (stasiun 11), terdapat massa air yang memiliki nilai oksigen sama dengan $6 \mathrm{mg} / \mathrm{l}$ pada kedalaman 80 $90 \mathrm{~m}$. Hal tersebut lebih mengindikasikan adanya sumber lain yang mampu meningkatkan konsentrasi oksigen. 
Pada kedalaman 100-200 m, oksigen terlarut di stasiun 11 menunjukan perubahan konsentrasi mulai dari $5 \mathrm{mg} / \mathrm{l}$ hingga $4 \mathrm{mg} / \mathrm{l}$. Perubahan tersebut memperlihatkan pemanfaatan oksigen pada lapisan tersebut (respirasi). Pada kedalaman $170-200 \mathrm{~m}$ di bujur $115.65^{\circ} \mathrm{E}-115.7^{\circ} \mathrm{E}$, terdapat oksigen yang lebih rendah dibandingkan dengan bujur lainnya pada kedalaman yang sama. Hal tersebut juga ditemukan pada kedalaman 80-90 m namun konsentrasinya lebih tinggi (oksigen terlarut $=6 \mathrm{mg} / \mathrm{l}$ ).Di bagian timur Selat Lombok (kedalaman 60-300 m), kandungan oksigen terlarut memiliki stratifikasi yang kecil dimana konsentrasi oksigen pada kedalaman tersebut cenderung tidak mengalami perubahan yang signifikan. Nilai oksigen terlarut pada kedalaman tersebut berkisar 4,23-4,80 mg/l.Nilai oksigen semakin menurun konsentrasi terutama pada kedalaman $225 \mathrm{~m}$ di sisi barat hingga $350 \mathrm{~m}$ di sisi timur Selatan Selat Lombok. Hal yang sama juga dapat dilihat pada konsentrasi oksigen 2,5 $\mathrm{mg} / \mathrm{l}$. Rendahnya nilai oksigen tersebut disebabkan oleh dangkalnya bagian barat selat lombok dibandingkan dengan bagian timur, sehingga pengaruh kedalaman tersebut berpengaruh terhadap nilai oksigen terlarut. Faktor suhu dan salinitas juga berpengaruh terhadap nilai oksigen. Pada kedalaman dasar, nilai suhu semakin rendah, namun salinitas semakin tinggi (Garcia dan Gordon, 1992).

Kandungan oksigen terlarut di perairan umumnya diukur untuk mengetahui perubahan proses kimia dan biologi yang terjadi. Oksigen meningkat disebabkan oleh proses fotosintesis dan berkurang disebabkan oleh respirasi oleh organisme serta oksidasi bahan organik oleh bakteri (Millero et al., 2002). Pada lapisan permukaan, kandungan oksigen cenderung meningkat kemudian semakin bertambah kedalaman, kandungannya semakin berkurang. Aktivitas fotosintesis yang berkurang pada lapisan dibawah termoklin mengakibatkan nilai oksigen berkurang.Pada daerah eufotik, umumnya kelebihan oksigen diatas saturasi atmosfer yang disebabkan oleh adanya produksi biologi bersih (net biological production) dari fitoplankton (Millero dan Sohn, 1992). Hal ini disebabkan oleh adanya stratifikasi densitas yang kuat yang menghambat pengadukan vertikal (vertical mixing) sehingga akan mengisolasi lapisan permukaan dan atmosfer. Hal yang berbeda pada lapisan termoklin, dimana daerah tersebut berada dibawah saturasi (Libes, 1992).
Hasil analisis kandungan oksigen terlarut di Selat Lombok menunjukan bahwa perairan yang dekat dengan pesisir cenderung memiliki oksigen terlarut yang rendah dibandingkan lepas pantai (Gambar 6). Hal ini dapat dilihat berdasarkan sebaran horisontal oksigen dimana stasiun 2, 3, 6, 7 dan 9 cenderung lebih rendah dibandingkan dengan stasiun lainnya (Gambar 6). Penyebab rendahnya nilai oksigen di daerah pesisir disebabkan oleh banyaknya masukan limbah organik. Oksigen yang ada akan dimanfaatkan oleh bakteri untuk menguraikan zat organik menjadi anorganik. Libes (1992) menyatakan bahwa bahan organik yang ada di suatu perairan dibagi menjadi dua, yaitu berasal dari lapisan permukaan yang kemudian akan tenggelam (sinking) ke lapisan yang lebih dalam. Selain itu, bahan organik juga berasal dari perairan lain yang terbawa oleh massa air dan melintasi ke perairan lain sehingga akan berdampak pada rendahnya kandungan oksigen.

Berdasarkan hasil penelitian Susanto et al., (2005), utara Selat Lombok lebih dalam dibandingkan dengan stasiun tengah dan selatan. Hal ini diduga berpengaruh terhadap konsentrasi oksigen terlarut dimana aliran massa air secara vertikal yang bergerak dari Pasifik ke Hindia melalui Selat Lombok, mempunyai mekanisme tersendiri untuk membawa oksigen hingga ke lapisan dalam (Ramesh et al., 2013). Pada bagian tengah, nilai oksigen cenderung tinggi dan nilainya semakin meningkat saat keluar selat. Adanya sill (bukit laut) yang berada disekitar stasiun 8 mampu meningkatkan kandungan oksigen. Massa air yang membawa oksigen dari utara Selat lombok yang cenderung lebih dalam (1400 m), kemudian masuk ke Selat Lombok yang lebih dangkal. Kemudian massa air tersebut terus bergerak menuju permukaan dikarenakan sill (bukit laut). Proses pengadukan dan difusi dari atmosfer ke permukaan menyebabkan nilai oksigen semakin meningkat. Hasil penelitian yang dilakukan sejak 2005 kegiatan ITF Cruise, puncak sill tersebut adalah $250 \mathrm{~m}$ (Susanto et al., 2005). Nilai oksigen tersebut makin tinggi setelah melewati sill terutama pada lapisan permukaan di stasiun 11 dan 12.Tingginya nilai oksigen di selatan Selat Lombok dipengaruhi oleh massa airyang berasal dari Samudera Hindia.Massa air dari Samudera Hindia yang lebih dingin bertemu dengan massa air Samudera Pasifik yang lebih hangat bertemu di selatan Lombok/keluaran ITF 
sehingga terjadi pengadukan (mixing) dan mempengaruhi oksigen terlarut (Fieux et al., 1996).

\subsection{Pengaruh Suhu dan Salinitas Terhadap Oksigen}

Suhu dan salinitas sangat mempengaruhi nilai oksigen terlarut di perairan. Semakin tinggi suhu dan salinitas, maka daya larut (NAEC) akan menurun. NAEC dapat dihitung pada saat konsentrasi gas yang ada dalam massa air saat berkesetimbang dengan atmosfer pada suhu dan salinitas insitu. Garcia dan Gordon (1992) memformulasikan hubungan antara suhu dan salinitas terhadap NAEC. Hasil dari analisis tersebut menunjukan bahwa nilai NAEC $\left(\mathrm{cm}^{3} \mathrm{dm}^{-3}\right.$ dan $\mu$ mol $\mathrm{kg}^{-1}$ ) pada kondisi kamar (STP) dapat dihasilkan pada kisaran suhu $\mathrm{t}_{\mathrm{F}} \leq \mathrm{t} \leq 40^{\circ} \mathrm{C}$ dan salinitas $0 \leq \mathrm{S} \leq 42$ psu.

Berdasarkan hasil perhitungan NAEC pada seluruh stasiun di Selat Lombok menunjukan bahwa semakin rendah suhu, maka nilai NAEC akan semakin tinggi, namun sebaliknya jika suhu tinggi, nilai NAEC akan rendah (Gambar 7). Pada bagian utara Selat Lombok (St. 1-3) (Gambar 7A), nilai NAEC berkisar antara 4,44-7,90 ml/l.

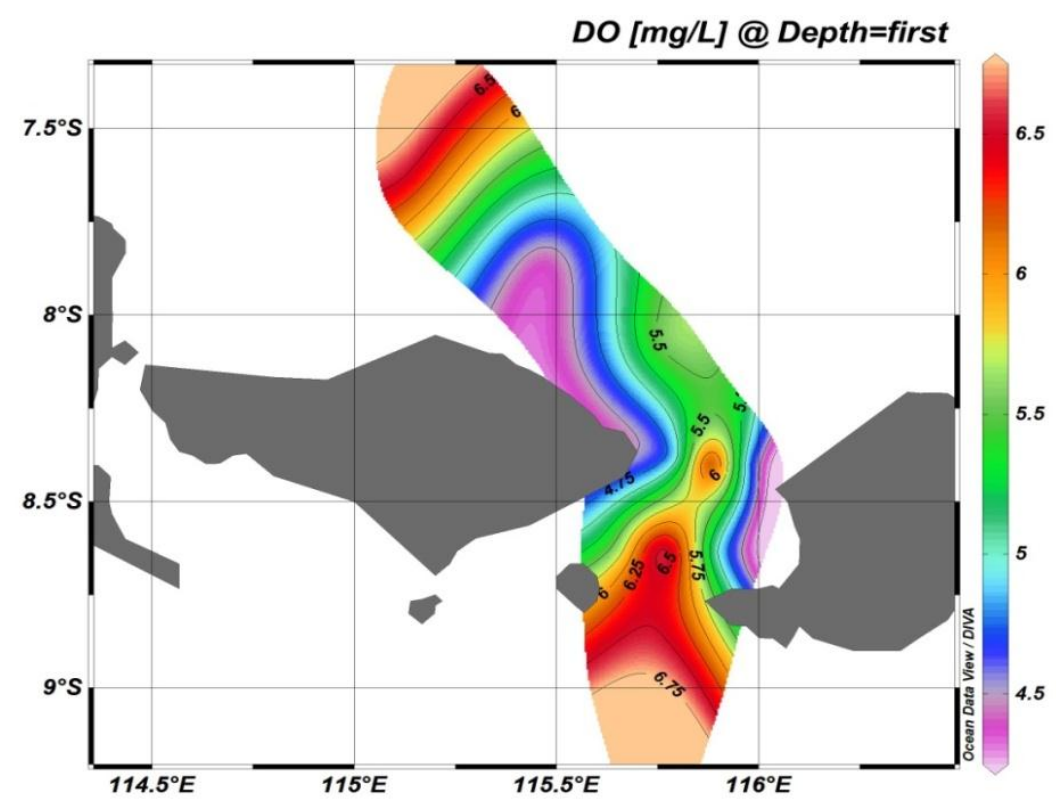

Gambar 6. Distribusi horisontal oksigen terlarut di Selat Lombok.

Figure 6. Horizontal distribution of dissolved oxygen in Lombok Strait Sumber: Hasil pengolahan data

Kisaran nilai tersebut umumnya hampir sama di ketiga stasiun, namun pada stasiun 1 mempunyai nilai maksimum yang lebih rendah dibandingkan stasiun 2 dan 3 (St. $1=4,45-7,55 \mathrm{mg} / \mathrm{l}$; St. $2=$ 4,44-7,88 mg/l; St. $3=4,44-7,90 \mathrm{mg} / \mathrm{l})$. Hal tersebut diakibatkan oleh kedalaman dasar yang dianalisis pada stasiun 1 lebih dangkal $(650 \mathrm{~m})$ dibandingkan dengan dengan stasiun $2(1000 \mathrm{~m})$ dan $3(1000 \mathrm{~m})$ dan berpengaruh terhadap nilai suhu dan salinitas. Dikarenakan terdapat hubungan ekponensial antara suhu dan salinitas terhadap NAEC,serta suhu dan salinitas sangat berpengaruh terhadap kedalaman, maka kedalaman dalam hal ini secara implisit mempengaruhi nilai NAEC.

Pada bagian tengah Selat Lombok, nilai NAEC berkisar antara 4,47-7,96 mg/l (Gambar 7B). Nilai NAEC tertinggi dan terendah terdapat pada stasiun 6 kedalaman $1000 \mathrm{~m}$ dan $25 \mathrm{~m}$. Adanya perbedaan kedalaman yang diamati pada stasiun bagian tengah ini menyebabkan nilai NAEC juga berbeda. Terlihat bahwa stasiun 7 merupakan stasiun yang paling rendah kisaran nilai NAECnya dibandingkan stasiun lainnya dibagian tengah yaitu 4,68-6,45 mg/l. Stasiun 7 sendiri berlokasi 
di dekat Nusa Penida yang merupakan bagian dari Selat Badung dengan kedalaman maksimal $250 \mathrm{~m}$. Sama halnya dengan bagian utara dan tengah Selat Lombok, nilai NAEC di bagian selatan (St. 11 dan 12) akan semakin tinggi konsentrasinya dengan bertambah kedalaman (Gambar 7C). Kisaran nilai NAEC pada stasiun ini adalah 3,847,16 mg/l. Stasiun $11(3,84-5,65 \mathrm{mg} / \mathrm{l})$ cenderung lebih rendah nilai NAEC-nya dibandingkan dengan stasiun 12 (4,57-7,16 mg/l).

Di laut, oksigen yang dikonsumsi/dimanfaatkan saat massa air berada di lapisan permukaan terutama untuk proses respirasi dan penguraian zat-zat organik oleh mikroorganisme dikenal dengan AOU. Berdasarkan rumus perhitungan, AOU juga bisa dihitung apabila daya larut oksigen awal diketahui, kemudian dikurangi dengan hasil pengukuran insitu. Nilai AOU yang tinggi mencerminkan kandungan oksigen yang berkurang pada lapisan permukaan. Artinya pada perairan tersebut, oksigen masih tersedia untuk proses respirasi dan penguraian bahan organik. Nilai AOU kadang menunjukan nilai yang negatif dan menandakan oksigen yang dibutuhkan lebih banyak daripada oksigen yang tersedia (Simanjuntak, 2007). Hasil pengukuran AOU di utara Selat Lombok menunjukan bahwa semakin tinggi suhu, maka nilai AOU semakin rendah. Nilai AOU pada bagian utara (St 1-3) berkisar antara $-2,38-5,40 \mathrm{mg} / \mathrm{l}$ (Gambar 7). Pada stasiun 1 , nilai AOU terendah ditemukan pada kedalaman $75 \mathrm{~m}$ yaitu- $2,38 \mathrm{mg} / \mathrm{l}\left(\mathrm{t}=26,5^{\circ} \mathrm{C}\right.$; $\left.\mathrm{s}=34,27 \mathrm{psu}\right)$ dan kedalaman $25 \mathrm{~m}$ yaitu $-2,42 \mathrm{mg} / \mathrm{l} \quad\left(\mathrm{t}=29,82^{\circ} \mathrm{C}\right.$; $\mathrm{s}=33,92 \mathrm{psu}$ ). Nilai tersebut merupakan nilai AOU terendah yang ditemukan pada bagian utara Selat Lombok. Rendahnya nilai AOU pada kedalaman tersebut mengindikasikan bahwa jumlah oksigen terlarut yang dibutuhkan jauh lebih banyak dibandingkan dengan jumlah oksigen yang tersedia. Selain itu, oksigen yang terukur diperairan lebih besar dibandingkan dengan nilai saturasi yang diduga diakibatkan terdapat masukan flux oksigen ke Selat Lombok yang dibawa oleh massa air. Dari Gambar 7A, dapat dilihat pula nilai AOU dibawah nilai $0 \mathrm{mg} / \mathrm{l}$ terutama pada stasiun 1 dan 3. Umumnya nilai AOU tersebut ditemukan pada kedalaman 5 m, 25 $\mathrm{m}, 50 \mathrm{~m}$, dan $75 \mathrm{~m}$. Jika dihitung tingkat kejenuhan (persentase oksigen terukur dibagi dengan NAEC) pada kedalaman tersebut, dihasilkan nilai diatas $100 \%$. Hal tersebut menandakan bahwa pada kedalaman tersebut cenderung diatas saturasi (oversaturation).

Hal yang sama juga ditemukan pada bagian tengah Selat Lombok, namun nilai AOU pada daerah ini lebih tinggi dibandingkan dengan bagian utara. Nilai AOU pada bagian tengah berkisar antara $-1,93 \mathrm{~s} / \mathrm{d} 5,64 \mathrm{mg} / \mathrm{l}$ (Gambar 7B). Pada Stasiun 4 dan 5, nilai AOU negatif masingmasing ditemukan pada kedalaman $25 \mathrm{~m} \& 75 \mathrm{~m}$ $(-0,39 \mathrm{mg} / \mathrm{l} ;-1,40 \mathrm{mg} / \mathrm{l})$ dan $5 \mathrm{~m} \& 25 \mathrm{~m}(-0,78$ $\mathrm{mg} / \mathrm{l} ;-1,80 \mathrm{mg} / \mathrm{l})$. Sedangkan pada stasiun $6(-$ $0,30 \mathrm{mg} / \mathrm{l})$, stasiun $7(-0,99 \mathrm{mg} / \mathrm{l})$, stasiun $8(-1,93$ $\mathrm{mg} / \mathrm{l})$, dan stasiun $9(-0,53 \mathrm{mg} / \mathrm{l})$, nilai $\mathrm{AOU}$ negatif masing-masing ditemukan pada kedalaman $25 \mathrm{~m}$. Pada bagian selatan (stasiun 11 dan 12), nilai AOU berkisar antara -2,70 s/d 4,81 $\mathrm{mg} / \mathrm{l}$ (Gambar 7C). AOU negatif juga ditemukan pada kisaran kedalaman 5 m - 75 m. Kisaran AOU pada stasiun 11 dan 12 masing-masing adalah $0,63 \mathrm{~s} / \mathrm{d}-2,14 \mathrm{mg} / \mathrm{l}$ dan $-0,66 \mathrm{~s} / \mathrm{d}-2,70 \mathrm{mg} / \mathrm{l}$. Jika dilihat nilai AOU pada seluruh stasiun di Selat Lombok, nilai AOU negatif ditemukan pada lapisan permukaan yaitu kedalaman $5 \mathrm{~m}-75 \mathrm{~m}$. Semakin kepermukaan, nilai AOU semakin berkurang. Namun pada lapisan dalam yang ditandai oleh suhu yang rendah, nilai AOU menunjukan adanya peningkatan. Hal ini disebabkan oleh nilai oksigen pada lapisan tersebut cenderung lebih sedikit jika dibandingkan pada lapisan permukaan. Oksigen pada lapisan dalam digunakan untuk dekomposisi bahan organik. Efek dari dekomposisi tersebut adalah adanya regenerasi nutrien/remineralisasi seperti fosfat dan nitrat dimana pada lapisan dalam, konsentrasi kedua nutrient tersebut lebih tinggi dibandingkan pada lapisan termoklin, walaupun nilai $\mathrm{pH}$ pada lapisan dalam lebih rendah dibandingkan dengan lapisan termoklin (Jingyan, 1983; Libes, 1992). Adanya nilai negatif dari AOU di lapisan permukaan di Selat Lombok mengindikasikan supersaturasi kandungan oksigen terlarut yang disebabkan oleh meningkatnya suhu permukaan laut dan produksi oksigen yang dilakukan oleh fitoplankton melalui proses fotosintesis. Hal yang sama juga ditemukan di Perairan Teluk Klabat, Pulau Bangka dimana, nilai AOU pada lapisan permukaan hingga kedalaman $26 \mathrm{~m}$ memiliki nilai negatif yaitu $-1,53$ $-1,04 \mathrm{mg} / \mathrm{l}$ (Simanjuntak, 2007). 

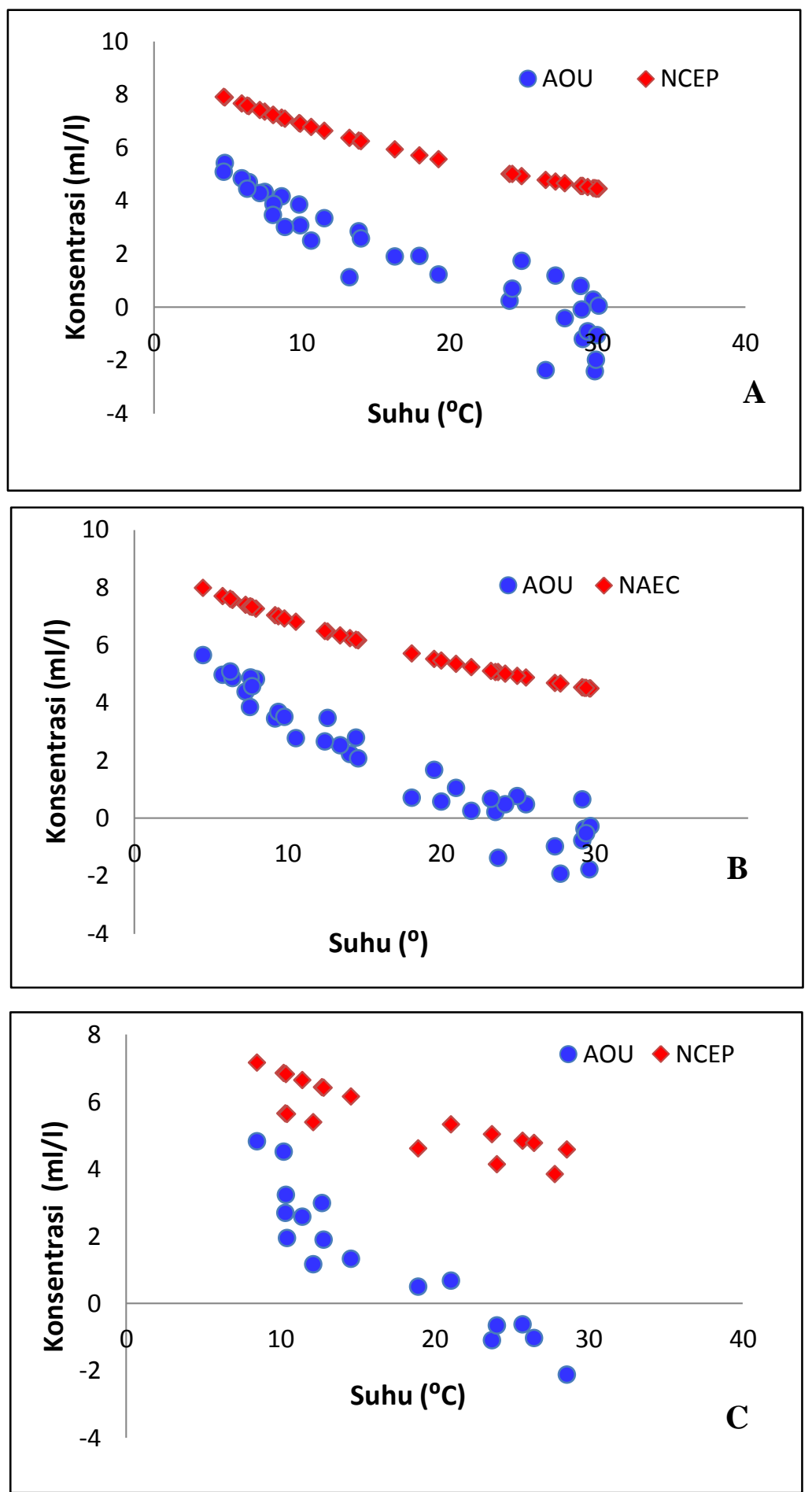

Gambar 7. Nilai Apparent Oxygen Utilization (mg/l) dan Normal Atmospheric Equilibrium Concentration (mg/l)di Selat Lombok. Utara Selat Lombok (St 1-3) (A), Tengah Selat Lombok (St. 4-9) (B) dan Selatan Selat Lombok (St. 11-12) (C).

Figure 7. Apparent Oxygen Utilization ( $m g / l)$ and Normal Atmospheric Equilibrium Concentration (mg/l) Values in Lombok Strait. Northern of Lombok Strait (St 1-3) (A), Middle of Lombok Strait (St. 4-9) (B)

and Southern of Lombok Strait (St. 11-12) (C)

Sumber: Hasil pengolahan data 


\subsection{Pengaruh Arus Lintas Indonesia Terhadap Oksigen Terlarut}

Selat Lombok merupakan salah satu lintasan ITF, dimana massa air yang melintasi Selat Lombok akan mempengaruhi kandungan oksigen terlarut. Untuk melihat pengaruh tersebut, maka dianalisis kandungan oksigen dan karakteristik massa air meliputi suhu, salinitas dan TS diagram pada jalur lintasan ITF ini yaitu St. 1, 2, 3, 4, 8, dan 11. Sebaran menegak suhu pada Gambar 8C memperlihatkan bahwa nilai suhu makin menurun dengan semakin meningkatnya kedalaman. Namun hal yang berbeda terlihat pada distribusi vertikal salinitas dimana nilainya akan semakin meningkat dengan meningkatnya kedalaman (Gambar 8B). Untuk mengetahui asal massa air yang melintas di Selat Lombok bisa diketahui berdasarkan TS-diagram (Gambar 8A).

Akibat adanya perbedaan nilai suhu terhadap kedalaman, maka terdapat tiga pola pelapisan massa air yaitu lapisan tercampur, lapisan termoklin dan lapisan dalam. Pada lapisan tercampur yang dicirikan oleh suhu berbentuk garis menegak umumnya mempunyai ketebalan lapisan homogen yang berbeda antarstasiun. Berdasarkan Gambar 8C, lapisan tercampur terbentuk sampai kedalaman 5-31 m dengan kisaran suhu mencapai $28,11{ }^{\circ} \mathrm{C}-30,05{ }^{\circ} \mathrm{C}$. Pada stasiun 1, lapisan tercampur ditemukan pada kedalaman $31 \mathrm{~m}$. Berbeda dengan stasiun yang lainnya dimana lapisan tercampur ditemukan lebih dangkal lagi (St. 2=21 m; St. 3=18m; St. 4= $28 \mathrm{~m}$; St. $8=18 \mathrm{~m}$; St. $11=5 \mathrm{~m})$. Pada kedalaman yang lebih dalam, suhu akan berubah secara drastis terhadap kedalaman dan membentuk suatu lapisan yang dikenal dengan istilah lapisan termoklin. Sama halnya dengan lapisan tercampur, ketebalan lapisan termoklin juga berbeda-beda. Hasil pengukuran menunjukan bahwa, suhu pada lapisan termoklin ditemukan sampai kedalaman 295-397 m dari batas akhir lapisan tercampur dengan kisaran suhu adalah $7,72{ }^{\circ} \mathrm{C}-28,11{ }^{0} \mathrm{C}$. Lapisan dalam keenam stasiun tersebut menunjukan nilai suhu yang berbeda-beda. Stasiun 2 dan 3 cenderung lebih dalam tentunya mempunyai lapisan dalam yang lebih luas dibandingkan stasiun yang lebih dangkal (St 1, 4, 8 dan 11). Suhu pada lapisan dalam ditemukan sampai kedalaman 372-1002 $\mathrm{m}$ dengan kisaran 4,47-7,72 ${ }^{\circ} \mathrm{C}$ (St. 2 dan 3), sampai kedalaman 372$750 \mathrm{~m}$ di stasiun $4\left(5,77-7,72{ }^{\circ} \mathrm{C}\right)$, kedalaman 651 -
$750 \mathrm{~m}$ di stasiun $1\left(6,43-7,72{ }^{\circ} \mathrm{C}\right)$ dan kedalaman 457-750 $\mathrm{m}$ di stasiun $8\left(7,49-7,72{ }^{\circ} \mathrm{C}\right)$.

Nilai salinitas semakin meningkat dengan bertambahanya kedalaman. hasil pengukuran menunjukan bahwa kedalaman pada lapisan tercampur sangat tipis yaitu berada pada 0-29 m dari permukaan dengan nilai salinitas berkisar 33,67 - 34,25 psu. Pada kedalaman yang lebih dalam, salinitas berubah dengan drastis terhadap kedalaman (haloklin). Salinitas pada haloklin ditemukan batas akhir lapisan tercampur hingga kedalaman 118-216 m dengan kisaran salinitas 34,56-34,71 psu. Pada lapisan dalam antarstasiun menunjukan perbedaan kedalaman yang berbeda. Stasiun 2 dan 3 mempunyai lapisan dalam dari batas akhir halokin hingga kedalaman $1002 \mathrm{~m}$ (34,58-34,58 psu), stasiun 4 hingga kedalaman $751 \mathrm{~m}(34,548 \mathrm{psu})$, stasiun 1 hingga kedalaman $651 \mathrm{~m}(34,55 \mathrm{psu})$, stasiun 8 hingga kedalaman $457 \mathrm{~m}(34,50 \mathrm{psu})$ dan stasiun 11 hingga kedalaman $398 \mathrm{~m}(34,73 \mathrm{psu})$.

Hasil analisis TS-diagram menunjukan bahwa pada lapisan permukaan, terdapat massa air yang sama yang melintas di Selat Lombok terutama di stasiun 1 dan 2 (suhu $=28,86{ }^{\circ} \mathrm{C}-29,96{ }^{\circ} \mathrm{C}$; salinitas $=33,73-34,18$ psu; sigma-t $(\mathrm{s} t)=20,8$ 21,1). Pada stasiun 3, massa air di permukaan cenderung dipengaruhi oleh massa air dari Laut Flores dan Laut Jawa (suhu $=29,98-30,03^{\circ} \mathrm{C}$; salinitas $=33,66-34,20 \mathrm{psu}$ ). Massa air dari Laut Jawa cenderung dominan membawa air tawar dibandingkan ITF sehingga salinitas menjadi rendah dipermukaan. Pengaruh ENSO dan curah hujan juga mempengaruhi nilai salinitas di Selat Lombok (Sprintall et al., 2003; Susanto et al., 2012). Pada Muson Barat (Januari-Maret), massa air bersalinitas rendah bergerak menuju timur hingga selatan Selat Makassar dan pada Musim Munson Tenggara (Musim Timur) membawa kembali ke Laut Jawa.

Berdasarkan Gambar 8A dapat dilihat adanya massa air bersalinitas maksimum yang memiliki karakteristik salinitas mencapai 34,71 psu, suhu $20,27{ }^{\circ} \mathrm{C}$ dan sigma-t (s t) 24,4 . Massa air tersebut ditemukan pada stasiun 4 pada kedalaman $139 \mathrm{~m}$. Jika dilihat kembali pada kedalaman 163-209 m, terdapat massa air yang memiliki salinitas 34,53134,58 psu, suhu $13,57-15,06^{\circ} \mathrm{C}$ dan sigma-t (s t) 25,4-25,8. Menurut Arief (1997), massa air tersebut merupakan sisa-sisa massa air Northern 
Subtropical Lower Water (NSLW). Massa air tersebut maksimum terbentuk di Samudera Pasifik bagian barat $\left(25^{\circ} \mathrm{LU} ; 165^{\circ} \mathrm{BT}-195^{\circ} \mathrm{BT}\right)$. Hal yang sama juga ditemukan pada Musim Barat 2004 dan Musim Timur 2005 di Selat Lombok dimana terdapat massa air bersalinitas maksimum dengan salinitas 34,60-34,62 psu, suhu $16-18{ }^{\circ} \mathrm{C}$ dan sigma-t (s t) 24,8-25,4 (Utami, 2006). Pada suhu potensial yang lebih rendah, terdapat massa air bersalinitas minimum yang memiliki karakteristik salinitas 34,48-34,54 psu, suhu $6,30-7,90^{\circ} \mathrm{C}$ dan sigma-t (s t) $26,70-27,20$ (Gambar 8A).
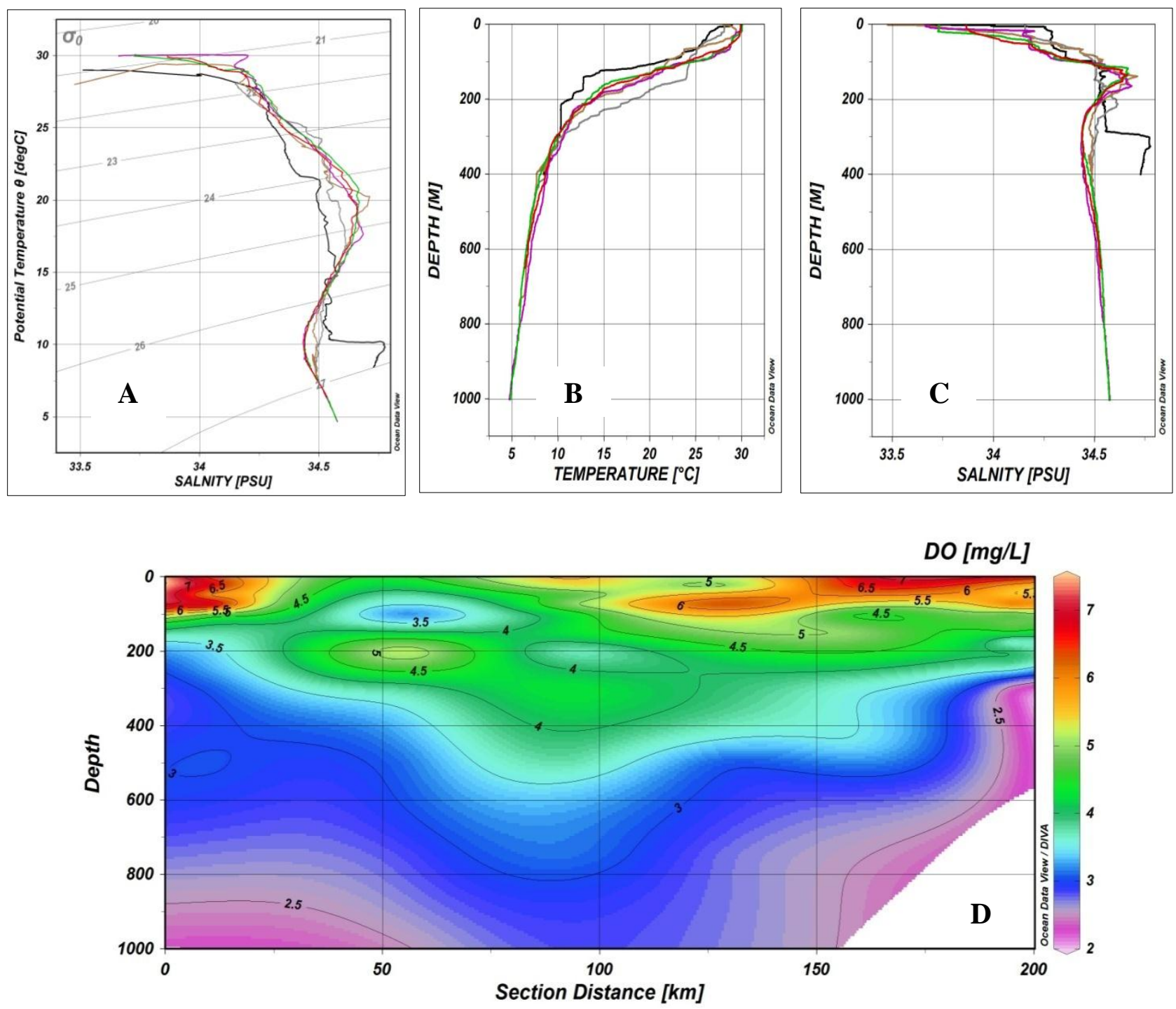

Gambar 8. Kurva potensial temperatur terhadap salinitas (A), Distribusi vertikal salinitas (B) dan Suhu (C) di Selat Lombok November 2013, kandungan oksigen terlarut di Stasiun 1, 2, 3, 4, 8, dan 11 (D). St.1 (merah), St.2 (hijau), St.3 (Ungu), St.4 (kuning coklat),St. 8 (abu-abu), dan St.11 (hitam).

Figure 8. Potential temperature-salinity curves (A), distribution of salinity (B) and temperature in Lombok Strait November 2013, and dissolved oxygen at station 1, 2, 3, 4, 8, and 11 (D). St.1 (red), St.2 (green),St.3 (purple), St.4 (yellow-bworn), St. 8 (Grey), and St.11 (black)

Sumber: Hasil pengolahan data 
Jika dilihat pengaruh massa air yang melintas di Selat Lombok terhadap kandungan oksigen terlarut, maka dapat dilihat bahwa terdapat stratifikasi oksigen antar kedalaman dari bagian utara (kiri) hingga selatan (kanan) (Gambar 8D). Pada bagian utara, cenderung bersalinitas rendah dan memiliki suhu permukaan yang tinggi, maka dihasilkan kandungan oksigen yang tinggi. Pada bagian tengah, nilai oksigen cenderung lebih rendah. Namun pada bagian ang lebih dalam, nilai oksigen cenderung lebih tinggi dibandingkan dengan utara dan selatan. Dibagian selatan, dikarenakan topografi lebih dangkal, maka nilai oksigen mengalami pengadukan sehingga dipermukaan cenderung lebih tinggi.

Selain dengan menggunakan suhu dan salinitas yang bersifat konservatif, asal usul massa air dapat diketahui berdasarkan parameter yang bersifat non konservatif seperti oksigen dan nutrien (nitrat dan fosfat) (Wyrtki, 1961). Hasil analisis TS-digram (Gambar 8A) memperlihatkan bahwa di Selat Lombok terdapat dua asal massa air yaitu NSLW dan NPIW. NSLW dicirikan oleh salinitas yang maksimum (suhu $=20-24{ }^{0} \mathrm{C}$; salinitas $=34,80-35,20$ psu dan oksigen 3,70-4,60 $\mathrm{ml} / \mathrm{l}$ ) sedangkan NPIW dicirikan oleh salinitas (suhu=7-11 ${ }^{0} \mathrm{C}$; salinitas $=34,10-34,50$ psu dan oksigen 1,70-3,00 $\mathrm{ml} / \mathrm{l})$ dan oksigen yang minimum (suhu $=4,0-9,0{ }^{0} \mathrm{C}$; salinitas $=34,30$ 34,60 psu dan oksigen 1,2-2,4 ml/l) (Wyrtki, 1961). Jika dilihat karakteristik kedua massa air tersebut, maka massa air NSLW di Selat Lombok berada di atas NPIW. Nilai oksigen dengan konsentrasi 30,70-4,60 $\mathrm{ml} / \mathrm{l}$ yang mencirikan massa air NSLW di utara Selat Lombok berada pada kedalaman 100-180 m kemudian bergerak ke arah selatan hingga kedalaman 100-550 m (bagian tengah) dan kembali ke permukaan pada kedalaman 190-220 m (selatan). Untuk massa air NPIW, keberadaannya tidak terlihat dengan menggunakan pendekatan oksigen terlarut dan hanya bisa dilihat dengan pendekatan suhu dan salinitas (TS-diagram).

\section{KESIMPULAN DAN SARAN}

Hasil pengukuran oksigen terlarut di bagian utara Selat Lombok berkisar 2,48-7,15 mg/l, tengah 2,32-6,58 $\mathrm{mg} / \mathrm{l}$, dan selatan 2,35-6,71 $\mathrm{mg} / \mathrm{l}$. Interaksi antara atmosfer dan air memperlihatkan adanya pertukaran oksigen menuju suatu kesetimbangan dimana lapisan permukaan lebih tinggi dibandingkan dengan lapisan dalam. Hal yang sama juga dilihat pada nilai AOU, semakin menuju lapisan dasar, nilainya semakin negatif. Hasil pengukuran suhu dan salinitas menunjukan bahwa Selat Lombok mempunyai suhu dan salinitas yang berkisar $4,74-30,08^{\circ} \mathrm{C}$ dan 33,48 34,78 psu.Terdapat dua massa air yang melintas di Selat Lombok saat pengukuran yaitu NSLW dan NPIW. NSLW ditemukan pada kedalaman 100180 (utara), 100-550 m (tengah) dan 190-220 m (selatan), sedangkan keberadaan lokasi NPIW tidak terlihat dengan menggunakan pendekatan oksigen terlarut dan hanya bisa dilihat dengan pendekatan suhu dan salinitas (TS-diagram).

\section{UCAPAN TERIMA KASIH}

Tulisan ini merupakan bagian dari kegiatan Indo China Cruise Expedition pada Balai Penelitian dan Observasi Laut, Balitbang KP, KKP. Ucapan terima kasih kasih kami sampaikan kepada Nyoman Surana, Gusti Putu Sukadana serta Crew dari KR Baruna Jaya IV yang telah membantu dalam pengambilan sampel.

\section{DAFTAR PUSTAKA}

Arief, D. (1997). Perubahan musiman karakteristik massa air Selat Lombok. J. Oseano dan Limno. Res., 30, 13-31.

Fieux M. R, Molcard, R., \& Illahude, A. G. (1996). Geostrophic transpor of the Pacific-Hindian oceans throughflow. J Geophys. Res. 101(C5): 12.421-12.432.

Garcia, H. E., \& Gordon, L. I,. (1992). Oxygen solubility in water: Better fitting equations. Limnology and Oceanography, 37, 1307-1312.

Gordon, A. L. (2005). Oceanography of the Indonesian Seas and their throughflow. Oceanography, 18(4), 14-27.

Grasshoff, K. (1976). Methods of Seawater Analysis. Verlog Chemie Weinhem. New York.

Jingyan, W. (1983). Vertical distribution of apparent oxygen utilization in nearshore water off Southern and Central Fujian. Acta Oceanologica Sinica, 2(1), 77-83.

Hani, D. Y. Q. (2006). Distribusi Vertikal Khlorofil-a dan Hubungannya dengan Nutrien di Perairan Laut Bali dan Selat Lombok. Skripsi. Program Studi Ilmu dan Teknologi Kelautan, FPIK, IPB. 
Hutagalung, H. P., Setiapermana, D., \& Riyono, S. H. (1997). Metode Analisis Air Laut, Sedimen dan Biota. Buku kedua. Jakarta: P3O-LIPI. 75-79.

Karang, I. W. G. A., Nishio, F., Mitnik, L., and Osawa, T. (2012). Spatial-temporal distribution and characteristic of internal waves in the Lombok Strait area studied by Alos-Palsar images. Earth Science Research, 1(2), 11-22.

Libes, S. M. (1992). An Introduction To Marine Biogeochemistry. John Wiley and Sons, Inc. New York.

Millero, F. J. \& Sohn, M. L.. (1992). Chemical Oceanography. CRC Press Inc. Boca Ruton. Ann Arbor. USA.

Millero, F. J., Huang, F., \& Lafereire, A. L. (2002). The solubility of oxygen in the major sea salts and their mixtures at $25^{\circ} \mathrm{C}$. Geochimica et Cosmochimica Acta, 66(13), 2349-2359.

Muray, S. P., \& Arief, D. (1988). Throughflow into The Indian Ocean through The Lombok Strait, January 1985-January 1986. Nature, 333, 444447.

Nybakken, J. W. (1988). Biologi Laut. Suatu Pendekatan Ekologi. Alih Bahasa oleh M. Eidman, Koesoebiono, D.G. bengen, M. Hutomo dan S. Sukarjo. Gramedia. Hal 459.

Parsons, T. R., Yoshiaki, M., \& Lalli, C. M. (1984). A Manual of Chemical and Biological Methods for Seawater Analysis. Pergamon Press, New York.

Ramesh, S., Ramadass, G. A., Ravichandran, M., \& Atmanand, M. A. (2013). Dissolved oxygen as a tracer for intermediate water mixing characteristics in the Indian Ocean. Current Science, 105(12), 1724-1729.

Redfield, A. C. (1942). The processes determining the concentrations of oxygen, phosphate, andrations of oxygen, phosphate, and other organic derivatives within the depths of the Atlantic Ocean. Phys. Oceanogr. Metcorol, 9(2), 1-22.

Riley, J. P., \& Chester, R. (1971). Introduction to Marine Chemistry. Academic Prees. London.

Schlitzer, R. (2013). Ocean Data View. http://odv.awi.de.

Simanjuntak, M. (2007). Oksigen terlarut dan apparent oxygen utilization di perairan Teluk Klabat, Pulau Bangka. Ilmu Kelautan, 12(2), 59-66.

Simanjuntak, M. (2012). Kaualitas air alut di tinjau dari aspek zat hara, oksigen terlarut dan $\mathrm{pH}$ di Perairan Banggai, Sulawesi Tengah. Ilmu dan Teknologi Kelauatan Tropis, 4(2), 290-303.

Sprintall, J., Potemra, T., Hautala, S., Bray, N. A., \& Pandoe, W. (2003). Temperature and salinity variability in the exits passages of Indonesian throughflow. In. Physical Oceanography of Indian Ocean during WOCE Period, F. Schott ed. Deep Sea Reseacrh, 50:2, 183-2,204.
Susanto, R. D., Mitnik, L., \& Zheng, Q. (2005). Internal waves observed in Lombok Strait. Oceanography, 18(4), 80-87.

Susanto, R. D., Gordon, A. L., \& Sprintall, J. (2012). Observations and proxies of surface layer throughflow in Lombok Strait. J. Geophys. Research, 112

Utami, I. N. (2006). Studi Karakteristik dan Aliran Massa Air Pada Musim Barat dan Musim Timur di Perairan Selat Lombok. Skripsi. Departemen Ilmu dan Teknologi Kelautan. Fakultas Perikanan dan Ilmu kelauatan, Institut Pertanian Bogor, Bogor.

Wyrtki, K. (1961). Physical Oceanography of Southeast Asian Water. Naga Report 2. Scripps Institution of Oceanography, $195 \mathrm{pp}$. 